\title{
FAKTOR-FAKTOR YANG MEMPENGARUHI KEJADIAN BURNOUT PADA PERAWAT DI RUANG INSTALASI RAWAT INAP RSUD RADEN MATTAHER DAN ABDUL MANAP JAMBI TAHUN 2017
}

\author{
Indah Mawarti dan Yusnilawati \\ Program Studi Keperawatan Fakultas Kedokteran Dan Ilmu Kesehatan Universitas Jambi \\ Kampus Pinang-Masak, Mendalo Indah Jambi 36361 \\ email: I.mawarti@yahoo.co.id; yusnilawati@yahoo.co.id
}

\begin{abstract}
ABSTRAK
Latar Belakang: Perawat adalah orang yang berinteraksi dengan klien selama 24 jam secara terus menerus. Perawat di ruang rawat inap memiliki potensi beban pekerjaan tinggi sehingga cenderung mengalami kelelahan dan kejenuhan. Kejenuhan kerja berdampak pada fisik, mental dan emosional perawat. Penelitian ini bertujuan untuk mengetahui faktor-faktor yang mempengaruhi burnout pada perawat di ruang instalasi rawat inap Rumah Sakit Umum Raden Mattaher dan rumah Sakit Abdul Manap Jambi. Metode: Penelitian ini merupakan penelitian deskriptif analitik dengan desain cross sectional. Sampel yang digunakan 96 perawat di ruang instalasi rawat inap Rumah Sakit Umum Raden Mattaher Jambi dan 101 perawat di Ruang rawat inap Rumah sakit abdul manap Jambi. Analisis data dilakukan secara univariat dan bivariat menggunakan uji chi square Hasil: Hasil penelitian menunjukkan bahwa perawat yang mengalami burnout tingkat ringan sebanyak $77,7 \%$, untuk variabel tingkat pendidikan, jenis kelamin, status pernikahan, dan masa kerja perawat tidak terdapat hubungan dengan burnout ( $>0,05)$, sedangkan beban kerja berhubungan dengan burnout $(\mathrm{p}<0,05)$. Kesimpulan: Tidak terdapat hubungan antara jenis kelamin, tingkat pendidikan,pernikahan, masa kerja dengan burnout pada perawat, sedangkan beban kerja terdapat hubungan dengan burnout pada perawat di ruang instalasi rawat inap Rumah Sakit Umum Raden Mattaher dan Rumah sakit Abdul |manap Jambi. Rumah sakit agar lebih memperhatikan perawat dalam tingkat kejenuhan dan beban kerjanya.
\end{abstract}

\section{Kata Kunci: Kejenuhan Kerja, Beban Kerja, Masa Kerja, Jenis Kelamin, Status Pernikahan Perawat.}

\section{PENDAHULUAN}

Tenaga kesehatan adalah setiap orang yang mengabdikan diri dalam bidang kesehatan serta memiliki pengetahuan dan/atau keterampilan melalui pendidikan di bidang kesehatan dalam jenis tertentu yang memerlukan kewenangan untuk melakukan upaya kesehatan. Tenaga di bidang kesehatan terdiri dari tenaga kesehatan dan asisten tenaga kesehatan. Tenaga kesehatan dikelompokkan ke dalam : tenaga medis, tenaga psikologi klinis, tenaga keperawatan, tenaga kebidanan, tenaga kefarmasian, tenaga kesehatan masyarakat, tenaga kesehatan lingkungan, tenaga gizi, tenaga keterapian fisik, tenaga keteknisian medis, tenaga teknik biomedika, tenaga kesehatan tradisional dan tenaga kesehatan lain. Tenaga keperawatan merupakan anggota tenaga kesehatan di garis terdepan yang menghadapi masalah kesehatan klien dan paling banyak berinteraksi dengan klien selama 24 jam secara 
terus menerus. Selain tugas pokok, perawat juga harus melakukan tugas tambahan lainnya seperti administrasi pasien, tugas sebagai tim ambulance dan lain-lain ${ }^{1}$.

Data World Health Organization (WHO) pada tahun 2012 menyatakan Indonesia masuk 6 negara di Asia Tenggara dan Asia Selatan yang kekurangan jumlah tenaga kesehatan terlatih baik dilevel dokter, perawat, maupun bidan. Pada tahun 2012 Indonesia juga menempati posisi ke-4 sebagai negara dengan angka kematian paling tinggi diantara negara-negara ASEAN. Hal ini menunjukkan bahwa kurangnya jumlah tenaga kesehatan yang mempengaruhi tingkat kesehatan masyarakat Indonesia masih rendah ${ }^{3}$. Melalui strategi global sumber daya manusia (SDM) kesehatan untuk tenaga kesehatan 2030, WHO menargetkan untuk optimalisasi tenaga kesehatan dalam mengejar tujuan pembangunan kesehatan yang berkelanjutan dan Universal Health Coverage (pendidikan, pekerjaan dan retensi), antisipasi kebutuhan tenaga kesehatan pada 2030, memperkuatan kapasitas individu dan lembaga untuk mengelola kebijakan SDM kesehatan dan memperkuatan data, bukti dan pengetahuan agar biaya yang dikeluarkan dalam pengambilan kebijakan dapat efektif.

Pada tahun 2015, total SDM kesehatan di Indonesia sebanyak 876.984 orang yang terdiri dari 647.170 orang tenaga kesehatan $(73,8 \%)$ dan 229.814 orang tenaga penunjang kesehatan $(26,2 \%)$. Perawat merupakan jumlah tenaga kesehatan terbanyak yang ada di Indonesia yaitu 147.264 perawat dengan rasio 87,65 per 100.000 penduduk, dengan data jumlah penduduk pada tahun 2015 sebesar 255.461.686 jiwa. Hal ini masih jauh dari target tahun 2019 yaitu 180 per 100.000 penduduk dan angka ini juga masih belum mencapai target tahun 2014 yang sebesar 158 per 100.000 penduduk. Jumlah penduduk Provinsi Jambi adalah 3.402.052 jiwa, dengan jumlah perawat sebanyak 3694 perawat memiliki rasio 108,58 per 100.000 penduduk yang masih di bawah target yang ditetapkan oleh kementerian keseharan Republik Indonesia 5 .

Jumlah perawat yang dibawah target pemerintah masih bisa diatasi dengan membuat perencanaan ketenagaan yang benar-benar diperhitungkan sehingga tidak mengakibatkan beban kerja yang tinggi dan turunnya kualitas pelayanan keperawatan. Penelitian yang dilakukan oleh Dewi dan Wiku di Rumah Sakit Umum Daerah Gunung Jati Cirebon tahun 2005, menemukan bahwa beban kerja berhubungan dengan kepuasan kerja perawat, karena bekerja dengan beban kerja yang proporsional akan lebih efektif serta dapat meningkatkan produktifitas $^{7}$. Sistem kerja yang tidak dirancang dengan baik dapat menyebabkan keluhan beban kerja berat, tidak efektif dan tidak efisien yang pada akhirnya menimbulkan ketidakpuasan dalam bekerja ${ }^{6}$. Ketidakpuasan hasil kerja perawat menyebabkan antusias perawat terhadap pekerjaannya hilang, dan berakhir menjadi cynicism. Cynicism adalah sikap sinis yang cenderung menarik, sikap sinis merupakan cara untuk terhindar dari rasa kecewa. Karena kekecewaan yang dirasakan oleh perawat menyebabkan perawat merasa tidak berdaya dan berpikir semua tugas yang diberikan terasa berat (ineffectiveness).

Ketidakpuasan hasil kerja dengan peningkatan beban kerja menyebabkan kejadian burnout pada perawat. Burnout merupakan suatu keadaan dimana terjadi 3 aspek yaitu kelelahan emosional, depersonalisasi dan penurunan prestasi diri. Burnout atau kejenuhan kerja menjadi suatu masalah yang menyebabkan individu untuk tidak realistis dalam mencapai tujuan dan pada akhirnya kehabisan energi dan perasaan tentang dirinya dan orang-orang sekitarnya, akibatnya terjadi penurunan kepuasan kerja, memburuknya kinerja dan produktivitas yang rendah. Menurut penelitian yang dilakukan oleh Aiken dkk tahun 1993 berjudul Hospital 
nurse staffing and patient mortality, nurse burnout, and job dissatisfaction, dengan sampel sebanyak 10.184 perawat. Hasilnya menunjukkan bahwa $43 \%$ perawat yang diteliti memiliki nilai burnout yang relatif tinggi dan ketidakpuasan dengan pekerjaan mereka sehingga berniat untuk berhenti dari pekerjaan mereka dalam 12 bulan ke depan. Hanya $11 \%$ dari total sampel perawat yang tidak mengalami burnout dan puas terhadap hasil kerja serta tidak akan berhenti dari pekerjaannya. Hasil survei yang dilakukan Persatuan Perawat Nasional tahun 2009 di Makassar mendapat hasil $51 \%$ perawat sering mengalami stress kerja, pusing, lelah, kurang istirahat karena beban kerja yang terlalu tinggi dan menyita waktu. Perawat juga mendapatkan gaji yang rendah tanpa insentif yang memadai. Salah satu indikator dari burnout adalah exhaustion (kelelahan yang berlebihan). Dampak dari kelelahan adalah mudah letih, jenuh, mudah tersinggung, sedih, bahkan sampai tertekan. Dampak kelelahan ini sesuai yang terjadi di Amerika Serikat seperti yang dikutip Tribun News Internasional akibat kelelahan, perawat tidak sengaja menjatuhkan bayi, sehingga menyebabkan bayi mengalami keretakan pada tulang tengkorak, beruntungnya hasil tes menyatakan bahwa indikasi keretakan dapat sembuh total. Pihak rumah sakit tidak memberikan sanksi dan pemecatan karena kemungkinan indikasi kelelahan yang dialami oleh perawat diakibatkan oleh tuntutan pekerjaan.

Penelitian yang dilakukan oleh Dian berjudul hubungan beban kerja, faktor demografi, locus of control dan harga diri terhadap burnout syndrome pada perawat pelaksana di IRD RSUP Sanglah Denpasar, dengan variabel faktor demografi yang diteliti terdiri dari usia, jenis kelamin, status pernikahan, masa kerja dan tingkat pendidikan. Hasil dari penelitian ini adalah $79,2 \%$ responden dengan usia < 30 tahun mengalami burnout ringan sedangkan 20,8\% responden dengan usia >30 tahun cenderung mengalami burnout sedang, dan status pernikahan memiliki hubungan yang signifikan dengan burnout dimana 5\% responden yang sudah menikah mengalami burnout berat, sedangkan jenis kelamin dan burnout syndrome tidak memiliki hubungan yang bermakna, karena kemungkian disebabkan kurangnya pemerataan jumlah perawat berdasarkan jenis kelamin. Walaupun begitu penelitian ini menunjukkan bahwa perempuan cenderung mengalami tingkatan burnout yang lebih tinggi dibandingan laki-laki. Hasil penelitian ini bertolak belakang dengan penelitian yang dilakukan oleh Puspa Ayu dan Akde Triyoga berjudul kejenuhan kerja (burnout) dengan kinerja perawat dalam pemberian asuhan keperawatan, menemukan hasil burnout lebih dominan terjadi pada jenis kelamin laki-laki. Burnout harus diantisipasi karena memiliki dampak yang negatif. Dampak dari burnout dapat mengenai fisik, mental hingga emosional individu tersebut. Burnout menyebabkan masalah pada kesehatan fisik, depresi, hingga menarik diri dari lingkungan akibat kelelahan emosional. Pada tahun 2007, Nursing Times Magazine melakukan survei terhadap 2000 perawat, hasil survei mendapatkan hampir $70 \%$ perawat mengalami masalah kesehatan fisik dan mental, 40\% diantaranya mengatakan tekanan yang didapat di tempat kerja juga mempengaruhi kehidupan pribadinya, serta 1 dari 10 perawat menjadi perokok aktif. Royal College of Nursing (RCN) menyatakan survei tersebut menegaskan bahwa perawat berada di bawah tekanan, penghargaan yang rendah dan gaji yang rendah. Sehingga RCN mengatakan tidak mengejutkan bahwa tingkat kejenuhan perawat mempengaruhi kehidupan pribadi perawat.

Apapun penyebabnya, munculnya kejenuhan kerja berakibat kerugian di pihak individu maupun organisasi tempat bekerja. Adanya beban kerja dan kejenuhan kerja pada diri perawat 
akan menurunkan kualitas kerja perawat, apabila kualitas kerja perawat menurun maka tidak hanya pasien yang dirugikan tetapi juga perawat itu sendiri, institusi dan yang paling penting adalah dapat memperburuk kondisi pasien yang akhirnya menuju kepada penurunan mutu asuhan keperawatan. Kejenuhan kerja menjadi suatu masalah bagi organisasi apabila mengakibatkan produktivitas dan kinerja yang menurun. Dampak penurunan kinerja perawat akan mempengaruhi tingkat kepuasan pasien, karena terjadinya kesenjangan antara harapan pasien dengan kinerja layanan kesehatan khususnya layanan keperawatan. Tingkat kepuasan pasien di nilai melalui Indeks Kepuasan Masyarakat (IKM). Oleh karena itu, jika kejenuhan kerja dibiarkan dan tidak di identifikasi secara komprehensif, maka rumah sakit tempat perawat tersebut bekerja akan mengalami penurunan kualitas pelayanan. Lebih dari itu, citra perawat sebagai salah satu petugas kesehatan yang terdekat dengan pasien akan rusak di mata masyarakat. Rumah Sakit Umum Daerah (RSUD) Raden Mattaher Jambi merupakan rumah sakit umum milik Pemerintah Daerah Provinsi Jambi dan sebagai rumah sakit umum pendidikan tipe B, serta sebagai rumah sakit rujukan untuk Provinsi Jambi. Rumah sakit ini memiliki 14 ruangan instalasi rawat inap, 1 ruangan Instalasi Gawat Darurat (IGD), 4 ruangan intensive care, dan memiliki 20 ruangan rawat jalan (poli). Jumlah tenaga perawat yang bertugas di ruangan rawat inap pada tahun 2016 sebanyak 280 orang dan Rumah Sakit Abdul manap memiliki 179 perawat dengan 9 instalasi rawat inap, 1 Instalasi Rawat Gawat Darurat (IGD) dan 15 ruang rawat jalan (Poli).

Berdasarkan uraian diatas, peneliti tertarik untuk meneliti faktor-faktor yang mempengaruhi burnout pada perawat di instalasi rawat inap, peneliti tertarik dengan penelitian ini karena belum banyak yang meneliti mengenai faktor-faktor yang mempengaruhi burnout pada perawat khususnya perawat instalasi rawat inap di Rumah Sakit Umum Daerah Raden Mattaher dan rumah sakit abdul manap Jambi.

\section{METODE PELAKSANAAN}

Berdasarkan pada permasalahan yang diteliti, metode yang digunakan dalam penelitian ini adalah metode descriptive analatic dengan pendekatan kuantitatif yang menggunakan desain Cross Sectional, yang mana pendekatan ini merupakan suatu rancangan yang dilakukan peneliti untuk mengukur atau mengamati pada saat bersamaan tentang faktor-faktor yang mempengaruhi tingkat burnout pada perawat instalasi rawat inap RSUD Raden Mattaher dan rumah sakit abdul manap Jambi 2017. Pengambilan sampel dalam penelitian dengan cara purposive sampling dimana sabjek penelitian diambil sesuai dengan tujuan yang telah ditentukan oleh peneliti. Jumlah sampel di ruang rawat inap RSUD Raden Mattaher Jambi diambil sebanyak 6 ruangan dari 11 ruang rawat inap dengan jumlah sampel 96 responden dengan pertimbangan bahwa 5 ruangan tidak mendapatkan izin penelitian dari ruangan tersebut. Untuk Rumah Sakit Abdul Manap Jumlah sampel yang diambil hanya di ruang rawat inap dengan total sampling sebanyak 101 responden. Untuk perawat semua ruang poli dan IGD tidak dimasukan dalam sampel penelitian ini

Instrument yang digunakan dalam penelitian ini adalah kuesioner dengan berbagai pertanyaan dan pernyataan yang telah tersusun rapi dan sesuai dengan variabel terkait yang akan diajukan kepada responden dan langsung diisi oleh responden. Pada penelitian ini, peneliti menggunakan instrumen penelitian berupa kuesioner diambil dari Maslach Burnout 
Inventory (MBI). Kegunaannya untuk mengukur tingkat burnout pada perawat di ruangan instalasi rawat inap RSUD Raden Mattaher dan rumah sakit abdul manap. Pada saat pengisian kuesioner, peneliti akan menjelaskan kepada responden tentang cara pengisian kuesioner jadi responden hanya tinggal memberikan tanda sebagai jawaban pada lembar kuesioner.

\section{HASIL DAN PEMBAHASAN}

\section{Hasil Penelitian}

Berikut Tabel 1 yang menggambarkan tentang demografi dari perawat di ruang instalasi rawat inap RSUD Raden Mattaher dan Rumah Sakit Abdul Manap Jambi tahun 2017

Tabel 1. Distribusi Frekuensi Faktor Demografi Perawat di Instalasi Rawat Inap RSUD Raden Mattaher dan rumah sakit abdul manap tahun 2017

\begin{tabular}{|c|c|c|c|}
\hline \multicolumn{2}{|l|}{ No } & $\bar{f}$ & $\%$ \\
\hline \multicolumn{4}{|c|}{ Jenis Kelamin } \\
\hline 1 & Laki-laki & 37 & 18,8 \\
\hline 2 & Perempuan & 160 & 81,2 \\
\hline \multicolumn{4}{|c|}{ Tingkat Pendidikan } \\
\hline 1 & Profesional & 33 & 16,8 \\
\hline 2 & Vokasional & 164 & 83,2 \\
\hline \multicolumn{4}{|c|}{ Status Perkawinan } \\
\hline 1 & Tidak Kawin & 56 & 28,4 \\
\hline 2 & Kawin & 141 & 71,6 \\
\hline \multicolumn{4}{|c|}{ Masa Kerja } \\
\hline 1 & $1-5$ & 123 & 62,4 \\
\hline 2 & $6-10$ & 49 & 24,9 \\
\hline 3 & $11-15$ & 12 & 6,1 \\
\hline 4 & $16-20$ & 7 & 3,6 \\
\hline 5 & $>20$ & 6 & 3,0 \\
\hline
\end{tabular}

Berdasarkan tabel di atas Frekuensi terbanyak untuk jenis kelamin perawat dalam penelitian ini adalah perawat dengan jenis kelamin perempuan dengan $81,2 \%$.

Untuk Pendidikan perawat dalam penelitian ini paling banyak adalah DIII keperawatan yaitu 83,2\%. Pengkategorian tingkat pendidikan vokasional (SPK, DIII, DIV) dan pendidikan pofesional (Ners, M.Kep). Berdasarkan tabel di atas, juga dapat diketahui bahwa frekuensi terbanyak untuk status pernikahan perawat dalam penelitian ini adalah perawat yang telah menikah dengan $71,6 \%$. Frekuensi terbanyak untuk masa kerja perawat dalam penelitian ini adalah perawat dengan masa kerja 1-5 tahun yaitu 62,4\% dari jumlah total 197 responden.

\section{Gambaran Beban Kerja Perawat di Ruang Instalasi Rawat Inap RSUD Raden} Mattaher Jambi dan Rumah Sakit Abdul Manap jambi Tahun 2017.

Berikut Tabel 2 yang menggambarkan tentang beban kerja dari perawat di ruang instalasi rawat inap RSUD Raden Mattaher dan rumah Sakit Abdul Manap Jambi tahun 2017 
Tabel 2. Distribusi Frekuensi Responden Berdasarkan Beban Kerja Perawat di Instalasi Rawat Inap RSUD Raden Mattaher dan Rumah Sakit Abdul manap Tahun 2017

\begin{tabular}{cccc}
\hline No & Beban Kerja & $F$ & $\%$ \\
1 & Ringan & 41 & 20,8 \\
2 & Sedang & 100 & 50,8 \\
3 & Berat & 56 & 28,4 \\
\hline & Total & 197 & 100,0 \\
\hline
\end{tabular}

$f$ : frekuensi

$\%$ : persentasi

Berdasarkan tabel 2 di atas, dapat diketahui bahwa frekuensi terbanyak untuk beban kerja perawat dalam penelitian ini adalah perawat dengan beban kerja sedang sebanyak 100 oraqng perawat $(50,8 \%)$ dari 197 responden.

\section{Gambaran tingkat Burnout Perawat di Ruang Instalasi Rawat Inap RSUD Raden} Mattaher dan Rumah sakit Abdul Manap Jambi Tahun 2017.

Berikut Tabel 3 yang menggambarkan tentang burnout dari perawat di ruang instalasi rawat inap RSUD Raden Mattaher dan Rumah Sakit Abdul Manap Jambi tahun 2017.

Tabel 3. Distribusi Frekuensi Responden Berdasarkan Tingkat Burnout Perawat di Instalasi Rawat Inap RSUD Raden Mattaher Jambi dan Rumah Sakit Abdul Manap tahun 2017.

\begin{tabular}{cccc}
\hline No & Burnout & $F$ & $\%$ \\
1 & Ringan & 153 & 77,7 \\
2 & Sedang & 43 & 21,8 \\
3 & Berat & 1 & 5 \\
\hline & Total & 197 & 100,0 \\
\hline
\end{tabular}

$f:$ frekuensi

$\%$ : persentasi

Berdasarkan tabel 3 di atas, dapat diketahui bahwa frekuensi terbanyak untuk tingkat burnout perawat dalam penelitian ini terbanyak adalah perawat dengan tingkat burnout ringan dengan jumlah 153 orang $(77,7 \%)$ dari 197 responden.

\section{Hubungan Jenis Kelamin Dengan Burnout Pada Perawat di Ruang Instalasi Rawat Inap RSUD Raden Mattaher dan rumah sakit abdul manap Jambi Tahun 2017}

Dari hasil analisis bivariat tentang hubungan jenis kelamin dengan burnout pada perawat di RSUD Raden Mattaher dan Rumah Sakit Abdul Manap Jambi tahun 2017, dapat dilihat pada tabel 4.4 berikut ini: 
Tabel 4. Hubungan antara jenis kelamin terhadap burnout pada perawat di ruang Instalasi Rawat Inap RSUD Raden Mattaher dan Rumah Sakit Abdul Manap Jambi tahun 2017

No JK Burnout Total p-value

\begin{tabular}{ccccccccccc} 
& \multicolumn{1}{c}{ Ringan } & \multicolumn{1}{c}{ Sedang } & \multicolumn{2}{c}{ Berat } & & \\
& & $\sum$ & $\%$ & $\sum$ & $\%$ & $\sum$ & $\%$ & $\sum$ & $\%$ & \\
\hline 1 & $\mathrm{~L}$ & 28 & 75,7 & 9 & 24,3 & 0 & 0 & 37 & 100 & 0,825 \\
2 & $\mathrm{P}$ & 125 & 78,1 & 34 & $\mathbf{2 1 , 2}$ & 1 & 6 & 160 & $\mathbf{1 0 0}$ & \\
\hline & $\mathrm{T}$ & 153 & 77,7 & 43 & 21,8 & 1 & 5 & 197 & 100,0 &
\end{tabular}

$\begin{array}{ll}\sum & : \text { Jumlah } \\ \% & : \text { persentasi }\end{array}$

Berdasarkan tabel 4. di atas, diperoleh bahwa burnout banyak dialami oleh perawat yang berjenis kelamin perempuan. Berdasarkan uji analisis Chi-Square dengan tingkat kepercayaan 95\% $(\alpha=0,05)$ diperoleh $p$-value $(0,825)>\alpha(0,05)$, maka $\mathrm{H}_{0}$ diterima yaitu tidak ada hubungan jenis kelamin dengan tingkat burnout pada perawat di ruang instalasi rawat inap RSUD Raden Mattaher rumah sakit abdul manap Jambi tahun 2017

\section{Hubungan Tingkat Pendidikan Dengan Burnout Pada Perawat di Ruang Instalasi Rawat Inap RSUD Raden Mattaher dan Rumah Sakit Abdul Manap Jambi Tahun 2017.}

Dari hasil analisis bivariat tentang hubungan tingkat pendidikan dengan burnout pada perawat di RSUD Raden Mattaher dan Rumah Sakit Abdul Manap Jambi tahun 2017, dapat dilihat pada tabel 4.5 berikut ini:

Tabel 5. Hubungan antara tingkat pendidikan terhadap burnout pada perawat di ruang instalasi rawat inap RSUD Raden Mattaher dan Rumah Sakit Abdul Manap Jambi tahun 2017

No TP Burnout Total p-value

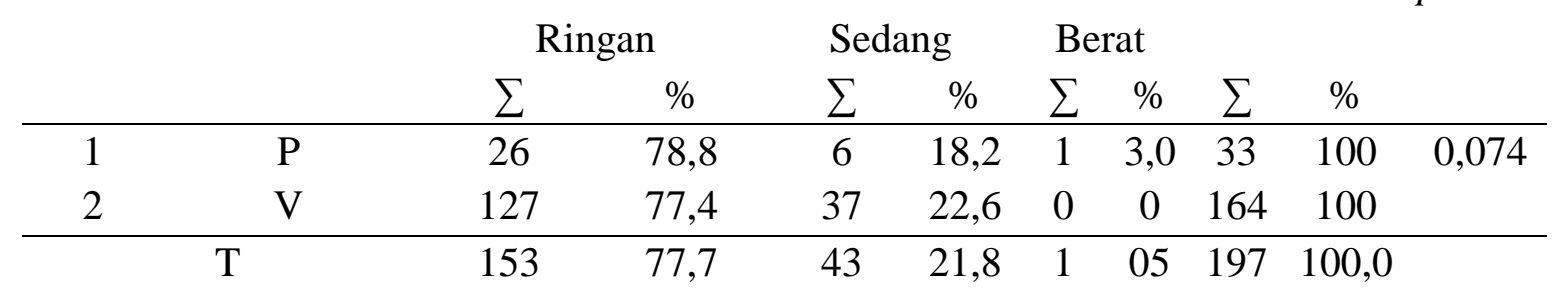

$\begin{array}{ll}\sum & : \text { Jumlah } \\ \% & : \text { persentasi }\end{array}$

Berdasarkan table 5 di atas, diperoleh bahwa burnout banyak dialami perawat dengan tingkat pendidikan vokasional. Berdasarkan uji analisis chi square dengan tingkat kepercayaan 95\% $(\alpha=0,05)$, maka diperoleh $p$-value $(0,074)>\alpha(0,05)$, maka maka $\mathrm{H}_{0}$ diterima yaitu tidak ada hubungan tingkat pendidikan dengan tingkat burnout pada perawat di ruang Instalasi Rawat Inap RSUD Raden Mattaher dan Rumah sakit Abdul Manaf Jambi tahun 2017. 


\section{Hubungan Status Pernikahan Dengan Burnout Pada Perawat di Ruang Instalasi Rawat} Inap RSUD Raden Mattaher dan Rumah Sakit Abdul Manap Jambi Tahun 2017.

Dari hasil analisis bivariat tentang hubungan antara faktor demografi dengan burnout pada perawat di RSUD Raden Mattaher dan rumah sakit abdul manap Jambi tahun 2017 dengan variabel status pernikahan, dapat digambarkan pada tabel 4.6 berikut ini:

Tabel 6. Hubungan antara status pernikahan terhadap burnout pada perawat di ruang instalasi rawat inap RSUD Raden Mattaher dan rumah sakit abdul manap Jambi tahun 2017

No SP Burnout Total p-value

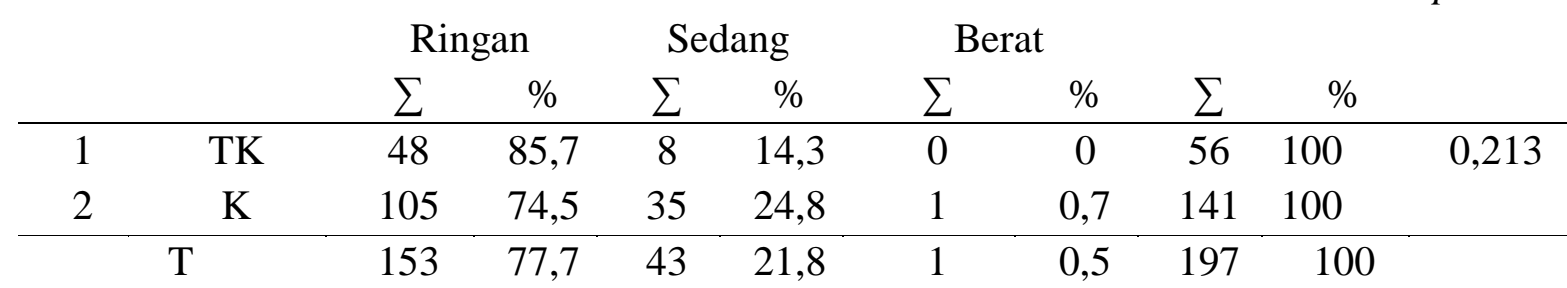

$\sum_{\%}$

: Jumlah

: persentasi

Berdasarkan tabel 6 di atas, diperoleh bahwa burnout banyak dialami perawat yang belum menikah dengan $85,7 \%$ untuk burnout ringan dan $24,8 \%$ untuk burnout sedang. Berdasarkan uji analisis Chi-Square dengan tingkat kepercayaan 95\% $(\alpha=0,05)$, maka diperoleh $p$-value $(0,213)>\alpha(0,05)$, maka $\mathrm{H}_{0}$ diterima yaitu tidak ada hubungan status pernikahan dengan tingkat burnout pada perawat di ruang instalasi rawat inap RSUD Raden Mattaher Jambi dan Rumah Sakit Abdul Manap tahun 2017.

\section{Hubungan Masa Kerja Dengan Burnout Pada Perawat di Ruang Instalasi Rawat Inap RSUD Raden Mattaher dan Rumah Sakit Abdul Manap Jambi Tahun 2017.}

Dari hasil analisis bivariat tentang hubungan antara masa kerja dengan burnout pada perawat di RSUD Raden Mattaher dan Rumah Sakit Abdul Manap Jambi tahun 2017 dengan variabel masa kerja, dapat digambarkan pada tabel 7 berikut ini:

Tabel 7. Hubungan antara masa kerja terhadap burnout pada perawat di ruang instalasi rawat inap RSUD Raden Mattaher dan rumah sakit abdul manap Jambi tahun 2017

No Masa Kerja

Burnout

Total p-value

\begin{tabular}{ccccccccccc} 
& & \multicolumn{2}{c}{ Ringan } & \multicolumn{1}{c}{ Sedang } & \multicolumn{2}{c}{ Berat } \\
& & $\sum$ & $\%$ & $\sum$ & $\%$ & $\sum$ & $\%$ & $\sum$ & $\%$ & \\
\hline 1 & $1-5$ & 100 & 81,3 & 23 & 18,7 & 0 & 0 & 123 & 100 & 0,098 \\
2 & $6-10$ & 38 & 77,6 & 10 & 20,4 & 1 & 2,0 & 49 & 100 & \\
3 & $11-15$ & 5 & 41,7 & 7 & 58,3 & 0 & 0 & 12 & 100 & \\
4 & $16-20$ & 5 & 71,4 & 2 & 28,6 & 0 & 0 & 7 & 100 & \\
5 & $>20$ & 5 & 83,3 & 1 & 16,7 & 0 & 0 & 6 & 100 & \\
\hline & Total & 153 & 77,7 & 43 & 21,8 & 1 & 0,5 & 197 & 100,0 &
\end{tabular}

$\sum:$ Jumlah

$\%$ : persentasi 
Berdasarkan tabel 4.7 di atas, diperoleh bahwa burnout banyak dialami perawat dengan masa kerja 1-5 tahun dengan 48,1\% untuk burnout ringan dan 40,7\% untuk burnout sedang. Berdasarkan uji analisis fisher dengan tingkat kepercayaan 95\% $(\alpha=0,05)$, maka diperoleh $p$ value $(0,098)>\alpha(0,05)$, maka $\mathrm{H}_{0}$ diterima yaitu tidak ada hubungan masa kerja dengan tingkat burnout pada perawat di ruang instalasi rawat inap RSUD Raden Mattaher dan Rumah Sakit Abdul Manap Jambi tahun 2017.

\section{Hubungan Beban Kerja Dengan Burnout Pada Perawat di Ruang Instalasi Rawat Inap RSUD Raden Mattaherdan Rumah Sakit Abdul Manap Jambi Tahun 2017}

Dari hasil analisis bivariat tentang hubungan antara beban kerja dengan burnout pada perawat di RSUD Raden Mattaher rumah sakit abdul manap Jambi tahun 2017, dapat digambarkan pada tabel 4.8 berikut ini:

Tabel 8. Hubungan antara beban kerja kerja terhadap burnout pada perawat di ruang instalasi rawat inap RSUD Raden Mattaher dan Rumah Sakit Abdul Manap Jambi tahun 2017

\begin{tabular}{ccccccccccc} 
& & \multicolumn{4}{c}{ Burnout } & \multicolumn{2}{c}{ Total } \\
No & BR & \multicolumn{2}{c}{ Ringan } & \multicolumn{2}{c}{ Sedang } & \multicolumn{2}{c}{ Berat } & \multicolumn{3}{c}{$p$-value } \\
& & $\sum$ & $\%$ & $\sum$ & $\%$ & $\sum$ & $\%$ & $\sum$ & $\%$ & \\
\hline 1 & $\mathrm{R}$ & 39 & 25,5 & 2 & 4,7 & 0 & 0 & 41 & 20,8 & \\
2 & $\mathrm{~S}$ & 76 & 49,7 & 24 & 55,8 & 0 & 0 & 100 & 50,8 & 0,015 \\
3 & $\mathrm{~B}$ & 38 & 24,8 & 17 & 39,5 & 1 & 100 & 56 & 28,4 & \\
\hline \multicolumn{2}{l}{ Total } & 153 & & 43 & & 1 & 100 & 197 & 100,0 &
\end{tabular}

$\sum$ : Jumlah

$\%$ : persentasi

Berdasarkan tabel 4.8 di atas, diperoleh data bahwa burnout sedang banyak dialami perawat dengan beban kerja sedang dengan 55,8\% Berdasarkan uji analisis Chi-Square dengan tingkat kepercayaan $95 \%(\alpha=0,05)$, maka diperoleh $p$-value $(0,015)<\alpha(0,05)$, maka $\mathrm{H}_{0}$ ditolak yaitu ada hubungan beban kerja dengan tingkat burnout pada perawat di ruang instalasi rawat inap RSUD Raden Mattaher dan Rumah sakit abdul manap Jambi tahun 2017.

\section{Pembahasan}

Hasil penelitian menunjukkan bahwa perawat yang mengalami burnout tingkat ringan $(77,7 \%)$ lebih banyak dari perawat yang mengalami burnout tingkat berat (5\%). Pada perawat dengan burnout tingkat ringan, hampir semua perawat tidak pernah memberikan perlakuan yang tidak semestinya pada pasien, tidak pernah mengalami perasaan dimana sudah tidak sanggup lagi bekerja karena merasa pekerjaan sudah terlalu berat dan merasa senang menjadi perawat dan bisa dekat dengan pasien. Pada perawat dengan burnout tingkat sedang, perawat sering merasakan kelelahan setiap akhir shift kerja, perawat sering khawatir pekerjaannya membuat perawat menjadi tidak peka dan perawat jarang merasa berpengaruh ke kehidupan pasiennya. Hasil penelitian ini mengacu pada 3 indikator burnout yaitu kelelahan emosional, depersonalisasi dan penurunan prestasi diri.

Hasil ini sejalan dengan hasil penelitian Akde dkk tentang kejenuhan kerja (burnout) dengan kinerja perawat dalam pemberian asuhan keperawatan pada perawat di ruang rawat 
inap Rumah Sakit Baptis Kediri, dimana sebagian besar responden merasa kelelahan di akhir shift kerja.

Berdasarkan hal diatas, menurut peneliti perawat di ruang rawat inap RSUD Raden Mattaher dan Rumah Sakit Abdul Manap secara keseluruhan lebih banyak mengalami burnout tingkat ringan karena lingkungan kerja dan umpan balik dari pasien sangat baik, sehingga perawat lebih bertanggung jawab dan tidak mudah menyerah pada pekerjaannya serta merasa lebih bahagia karena dekat dengan pasiennya. Walaupun begitu beberapa perawat merasa letih dan kelelahan sehabis bekerja, hal tersebut termasuk hal yang wajar, oleh karena itu sebagian besar perawat mengalami burnout ringan. Perawat berhadapan dengan bermacam-macam bentuk emosional dan berbagai kepribadian, baik dari rekan kerja maupun dari pasien, tetapi perawat tetap berusaha untuk percaya diri dan percaya akan kemampuannya sehingga sedikit perawat yang mengalami depersonalisasi dan penurunan prestasi diri. Burnout tingkat ringan perlu diperhatikan karena dapat meningkat menjadi burnout tingkat sedang hingga burnout tingkat berat. Perawat perlu meluangkan waktu untuk mereflesikan tindakan yang akan diambil dan yang telah diambil untuk mempertimbangkan penyebab kejenuhan yang dihadapi dan keseimbangan antara kerja dan hiburan, serta perawat perlu sistem dukungan sosial yang dimilikinya baik dari keluarga, teman maupun jaringan sosial lainnya.

Hasil penelitian menunjukkan bahwa perawat perempuan lebih banyak dari perawat lakilaki. Dari 160 perawat perempuan, 125 responden mengalami burnout tingkat ringan $(78,1 \%)$. Berdasarkan tabel 4.4 didapatkan bahwa jenis kelamin tidak berhubungan dengan burnout pada perawat di ruang instalasi rawat inap RSUD Raden Mattaher tahun 2017, dengan p-value 0.825. Teori Maslach menemukan bahwa pria cenderung mengalami depersonalisasi sedangkan wanita cenderung mengalami kelelahan emosional. Perbedaan jenis kelamin dapat mempengaruhi cara seseorang dalam menyikapi masalah di lingkungan. Hal ini terjadi karena pria dan wanita tumbuh dan dibesarkan dengan cara berbeda. Pria lebih cenderung bertindak tegas, tegar dan tanpa emosional, sedangkan wanita lebih pada perilaku kasih sayang dan lembut. Artinya, laki-laki cenderung menjaga jarak dengan penerima pasien, cenderung tidak peduli terhadap lingkungan serta orang-orang di sekitarnya dan mengurangi kontak dengan pasien. Penelitian ini sejalan dengan penelitian yang dilakukan oleh Suryani dkk pada perawat di RS UNHAS Makassar, dimana mendapatkan tidak ada hubungan antara jenis kelamin dengan burnout pada perawat dengan p-value 0,230. Menurutnya, hasil penelitian dapat dipengaruhi oleh kurangnya responden perawat laki-laki, sehingga variasi jawaban kecil/sedikit.

Berdasarkan hasil penelitian, perawat perempuan hampir semua tidak pernah memperlakukan pasiennya dengan tidak semestinya, karena selain perempuan lebih banyak menggunakan emosionalnya, perawat perempuan lebih tinggi tingkat kepeduliannya dibanding perawat laki-laki seperti yang dijelaskan oleh Maslach. Perawat perempuan banyak mengalami burnout tingkat ringan, walaupun begitu burnout pada perawat perempuan beresiko meningkat karena perempuan memiliki tanggung jawab dalam rumah tangga dan berperan sebagai istri dan ibu. Oleh sebab itu, diharapkan perawat perempuan dapat lebih mengontrol emosional dan dapat menjalin hubungan baik dengan rekan kerja sehingga kejenuhan dapat berkurang. Hasil penelitian menunjukkan bahwa perawat dengan tingkat 
pendidikan vokasional lebih banyak mengalami burnout tingkat ringan (77,4\%), sedangkan perawat dengan tingkat pendidikan professional lebih banyak mengalami burnout tingkat sedang $(78,8 \%)$. Berdasarkan tabel 4.5 didapatkan bahwa tingkat pendidikan berhubungan dengan burnout pada perawat di ruang instalasi rawat inap RSUD Raden Mattaher tahun 2017, dengan p-value 0,074. Menurut Maslach, burnout berhubungan dengan tingginya tingkat pendidikan. Perawat yang memiliki pendidikan tinggi cenderung rentan terhadap burnout, karena memiliki harapan atau aspirasi yang ideal sehingga ketika dihadapkan pada realitas bahwa terdapat kesenjangan antara aspirasi dan kenyataan, maka muncullah kegelisahan dan kekecewaan yang dapat menimbulkan burnout. Teori dari Siagian mengemukakan bahwa semakin tinggi tingkat pendidikan seseorang maka semakin besar keinginan untuk memanfaatkan pengetahuan dan keterampilan yang dimilikinya serta semakin besar pula tuntutan pekerjaan sehingga berpengaruh terhadap perilaku kerjanya. Hasil penelitian ini berbeda dengan penelitian yang dilakukan neli dkk tentang burnout dengan kinerja perawat di RS Metropolitan Medical Centre Jakarta. Penelitian ini juga menggunakan tingkat pendidikan sebagai variabelnya. Penelitian ini menyatakan bahwa tidak terdapat hubungan antara tingkat pendidikan dengan burnout pada perawat dengan p-value 0,6. Tingkat pendidikan vokasional di sejumlah rumah sakit menjadi mayoritas tingkat pendidikan perawat sama halnya di RSUD Raden Mattaher dan Rumah sakit Abdul manap Jambi, sehingga persepsi tentang jenjang pendidikan, tingkat pengetahuan dan peran dalam pelaksanaan keperawatan akan mempengaruhi dari burnout itu sendiri. Menurut hasil penelitian 33 responden dengan tingkat pendidikan professional (Ners), 26 responden mengalami burnout ringan dengan penurunan prestasi diri (low personal accomplishment) memiliki skor tinggi. Penurunan prestasi diri mengarah pada seseorang yang menilai rendahnya pencapaian dirinya, dan tidak membuat kemajuan. Hal ini dikaitkan dengan perawat yang lebih tinggi pendidikannya akan merasakan konflik karena apa yang diharapkan tidak ideal dengan realita Dan juga karena hampir setaranya jumlah beban kerja antara jenjang pendidikan, hanya sebagian kecil saja yang memiliki job description yang jelas. Oleh sebab itu, diharapkan rumah sakit dapat memberikan job description yang jelas pada perawat sesuai dengan tingkat pendidikan agar burnout perawat tidak meningkat dan berkurang dan diharapkan perawat dapat menghindari stressor dan memiliki strategi coping yang baik untuk menghindari peningkatan burnout.

Hasil penelitian menunjukkan bahwa perawat yang belum menikah lebih banyak mengalami burnout ringan $(85,7 \%)$ dan 1 orang perawat yang telah menikah mengalami burnout berat. Berdasarkan tabel 4.6 didapatkan bahwa status pernikahan tidak berhubungan dengan burnout pada perawat di ruang instalasi rawat inap RSUD Raden Mattaher dan Rumah Sakit Abdul Manap Tahun 2017 dengan p-value 0,213. Teori Maslach menjelaskan orang yang belum menikah mengalami tingkat burnout yang lebih tinggi. Menurut Farber, individu yang berstatus lajang tidak memiliki sistem pendukung yang baik dalam mendukung dan menunjang pekerjaan sehingga lebih rentan mengalami Burnout daripada yang telah menikah $^{37}$. Penelitian ini sejalan dengan penelitian Renny dkk tentang Analisis Karakteristik Individu Terhadap Kejenuhan pada perawat di ruang rawat inap dengan status pernikahan sebagai salah satu variabel yang diteliti. Penelitian ini mendapatkan bahwa tidak terdapat hubungan antara status pernikahan dengan burnout perawat dengan p-value 0,068 ${ }^{37}$. 
Berdasarkan hasil diatas, menurut peneliti responden yang telah menikah lebih banyak mengalami burnout ringan, karena perawat yang telah berkeluarga memiliki sistem pendukung atau orang-orang yang memberikan dukungan dalam keluarganya. Hal ini berpengaruh terhadap kemampuan perawat dalam mengatasi masalah di tempat kerja. Walaupun begitu perawat yang telah berkeluarga memiliki tanggung jawab secara financial maupun sosial. Perawat yang telah menikah juga memiliki tanggung jawab untuk menghidupi keluarga dan harus mampu untuk menjalankan fungsi sosial di masyarakat. Perawat perempuan yang telah menikah memilih bekerja untuk membantu memenuhi kebutuhan tersier keluarga karena tidak cukup jika hanya mengandalkan pendapatan dari suami. Perawat yang telah menikah juga mengalami konflik antara memilih keluarga atau menolong pasien. Seperti pengakuan beberapa perawat perempuan yaitu mereka harus meninggalkan keluarga yang sakit karena tanggung jawab professional dalam pekerjaannya. Perempuan yang bekerja dan sudah menikah sering merasa tidak bahagia. Hal ini umumnya terjadi karena merasa kewalahan dengan tanggung jawab, mengalami kesulitan dalam mempertahankan hubungan yang akrab dengan pasangan sehingga hal tersebut menimbulkan stress yang berkepanjangan. Oleh karena itu, pekerja yang telah menikah lebih sering menunjukkan skor kelelahan emosional. Pekerja yang telah menikah beresiko terjadi konflik terhadap peran gandanya. Konflik peran ganda pada wanita ada enam aspek harus dipertimbangkan, yaitu pengasuhan anak, bantuan pekerjaan rumah tangga, komunikasi dan interaksi dengan keluarga, waktu untuk keluarga, menentukan prioritas (pekerjaan atau keluarga), tekanan karir dan tekanan keluarga. Selain itu konflik yang terjadi ditempat kerja dapat mempengaruhi kehidupan di rumah tangga dan sebaliknya.

Hasil penelitian menunjukkan bahwa perawat yang masa kerja 1-5 tahun lebih banyak mengalami burnout ringan (81,3\%). Berdasarkan tabel 4.7 didapatkan bahwa masa kerja tidak berhubungan dengan burnout pada perawat di ruang Instalasi Rawat Inap RSUD Raden Mattaher dan Rumah Sakit Abdul manap Jambi Tahun 2017, dengan p-value 0,098. Teori Maslach menjelaskan bahwa pekerja pelayanan publik seperti perawat sering mengalami depersonalisasi sehingga menjauhkan diri dari pekerjaan yang menguras emosi. Pekerja dengan lama kerja yang dini cenderung lebih jenuh, karena baru memulai adaptasi dan menguasai pekerjaannya dan mulai belajar menguasai pekerjaan, oleh sebab itu semakin lama karyawan bekerja maka akan semakin terbiasa dengan pekerjaannya. Kejenuhan sering terjadi pada karyawan dengan masa kerja yang sedikit, karena semakin lama karyawan bekerja ia akan semakin terbiasa dengan pekerjaannya, sedangkan untuk karyawan yang baru memulai menguasai pekerjaannya dan mulai belajar menguasai pekerjaan secara tidak langsung dapat menjadi beban dan stress pada pegawai baru yang pada akhirnya dapat menyebabkan kejenuhan dalam bekerja. Hasil penelitian ini sejalan dengan penelitian Putu dkk tentang hubungan antara masa kerja dengan burnout pada perawat di ruang rawat inap anak RSUP Sanglah Denpasar. Penelitian ini mendapatkan bahwa tidak terdapat hubungan antara masa kerja dengan burnout pada perawat dengan p-value 0,10 . Berdasarkan hal diatas, peneliti berasumsi bahwa pekerjaan seperti perawat yang merupakan human service lebih cenderung memiliki pola kerja monoton dan pengalaman sebagai perawat sudah banyak dialaminya sehingga semakin meningkatkan kemampuannya dalam menghadapi situasi dalam pekerjaan. Perawat yang masa kerja diatas 5 tahun, lebih bisa mengerti dan dapat mengatasi 
kejenuhannya dari pengalaman yang perawat dapatkan. Tetapi walaupun begitu, posisi dan jabatan perawat dengan masa kerja diatas 6-10 tahun dapat menjadi alasan perawat mengalami burnout. Oleh sebab itu, diharapkan perawat dengan masa kerja dini dapat menambah pengalamannya dengan mengikuti pelatihan ataupun melakukan kerja sama dengan perawat yang memiliki masa kerja yang lama dan menjalin kerja sama yang baik antar tenaga kesehatan lain.

\section{Hubungan Beban Kerja terhadap Burnout Perawat di Ruang Instalasi Rawat Inap RSUD Raden Mattaher dan Rumah Sakit Abdul manap Jambi Tahun 2017.}

Hasil penelitian menunjukkan bahwa dari 100 orang perawat dengan beban kerja sedang sebanyak 76 (76,0\%) mengalami bournout ringan dan beban kerja berat sebanyak $(1,8 \%)$ mengalami bournout berat. Berdasarkan tabel 4.8 didapatkan bahwa beban kerja berhubungan dengan burnout pada perawat di ruang instalasi rawat inap RSUD Raden Mattaher dan Rumah Sakit Abdul Manap Tahun 2017, dengan p-value 0,015. Teori Maslach menyebutkan beban kerja dapat menyebabkan burnout pada individu akibat adanya tuntutan pekerjaan melebihi batas kemampuan individu. Beban kerja yang berlebihan menyebabkan individu merasa kelelahan dan apabila individu tidak dapat menanggulanginya maka akan menyebabkan kelelahan yang berkelanjutan dan menjadi burnout. Soehartati menyebutkan bahwa beban kerja yang berat menyebabkan perawat mengalami kelelahan dan menimbulkan stress kerja, stres kerja yang berlebihan pada perawat cenderung akan mengarah pada burnout. Penelitian ini sejalan dengan penelitian Widodo dkk tentang hubungan Antara Beban Kerja, Stress Kerja Dan Tingkat Konflik Dengan Kelelahan Kerja Perawat Di Rumah Sakit Islam Yogyakarta PDHI Kota Yogyakarta. Penelitian ini mendapatkan bahwa beban kerja memiliki hubungan yang signifikan dengan kelelahan kerja, dikarenakan bahwa lonjakan pasien di rumah sakit membuat beban kerja perawat semakin bertambah, sehingga juga memicu terjadi burnout di kalangan perawat. Berdasarkan hal diatas, peneliti berasumsi beban kerja dengan kategori tinggi berakibat pada kondisi fisik perawat yang menurun dan kelelahan. Beban kerja yang tidak sesuai disebabkan oleh beberapa hal seperti pembagian shift, gaya kepemimpinan kepala ruangan, komunikasi antar sejawat, reward, ketegasan akan kewajiban serta hak, Skor tertinggi variabel beban kerja terdapat pada indikator jumlah kerja. Hal ini menunjukkan bahwa pentingnya manajemen dalam menentukan kuantitas beban kerja yang disesuaikan dengan kemampuan yang dimiliki perawat, dan juga tergantung dari lokasi dan bagian perawat tersebut bekerja serta jumlah pasiennya. Hasil penelitian menyebutkan responden dengan beban kerja sedang lebih banyak mengalami burnout sedang, tapi jika dibiarkan secara terus-menerus, hal ini akan cenderung meningkat menjadi burnout yang lebih berat. Karena kelelahan fisik dalam jangka waktu yang lama dan terjadi secara terus menerus dapat menyebabkan dampak pada kelelahan psikologis.

Beban kerja perawat tidak hanya selalu jumlah pasien dan tindakan, tapi beberapa perawat memiliki persepsi selain jumlah pasien dan tindakan, kerja sama antar rekan kerja sesama perawat dan sesama tenaga medis termasuk dalam beban kerja. Oleh sebab itu, diharapkan rumah sakit lebih memperhatikan dan memperhitungkan beban kerja yang diberikan kepada perawat, dan perawat dapat menjalin kerja sama dengan baik antar rekan kerja agar terhindar dari burnout. 


\section{KESIMPULAN DAN SARAN \\ Kesimpulan}

Berdasarkan hasil penelitian yang telah dilakukan pada perawat di ruang Instalasi Rawat Inap RSUD Raden Mattaher dan Rumah Sakit Abdul Manap Jambi tahun 2017, diperoleh kesimpulan sebagai berikut:

1. Perawat di ruang instalasi rawat inap RSUD Raden Mattaher dan Rumah Sakit Abdul Manap Jambi paling tinggi mengalami burnout ringan sebanyak 77,7\%.

2. Tidak terdapat hubungan yang bermakna antara jenis kelamin dengan burnout pada perawat di ruang instalasi rawat inap RSUD Raden Mattaher dan Rumah Sakit Abdul Manap Jambi (pvalue > 0.05)

3. Tidak terdapat hubungan yang bermakna antara tingkat pendidikan dengan burnout pada perawat di ruang instalasi rawat inap RSUD Raden Mattaher dan Rumah Sakit Abdul Manap Jambi (pvalue $<0.05$ )

4. Tidak terdapat hubungan yang bermakna antara status pernikahan dengan burnout pada perawat di ruang instalasi rawat inap RSUD Raden Mattaher dan Rumah Sakit Abdul Manap Jambi (pvalue > 0.05)

5. Tidak terdapat hubungan yang bermakna antara masa kerja dengan burnout pada perawat di ruang instalasi rawat inap RSUD Raden Mattaher dan Rumah Sakit Abdul Manap Jambi (pvalue > 0.05)

6. Terdapat hubungan yang bermakna antara beban kerja dengan burnout pada perawat di ruang instalasi rawat inap RSUD Raden Mattaher dan Rumah Sakit Abdul Manap Jambi (pvalue <0.05)

\section{Saran}

1. Perlunya pembagian beban kerja yang proposional sesuai dengan tugas pokok dan fungsi perawat lebih jelas seperti perbandingan jumlah perawat dan jumlah pasien, sehingga perawat mampu bekerja lebih professional dan memberikan layanan yang optimal.

2. Bagi peneliti selanjutnya untuk dapat menganalisa lebih dalam tentang faktor yang mempengaruhi burnout selain beban kerja, jenis kelamin, tingkat pendidikan, status pernikahan dan masa kerja, dengan jumlah sampel yang lebih besar, pemilihan tempat penelitian yang lebih spesifik.

\section{DAFTAR PUSTAKA}

Undang-Undang Republik Indonesia Nomor 36 Tahun 2014 Tentang Tenaga Kesehatan World Health Organization.2012 (diakses 20 Januari 2017)

Kementerian kesehatan republik Indonesia. Profil Kesehatan Indonesia. 2012. (diakses 20 Januari 2017).

World Health Organization.2016 (diakses 20 Februari 2017). Diunduh dari: URL: http://www.who.int/hrh/resources/pub_globstrathrh-2030/en/

Kementerian kesehatan republic Indonesia. Profil Kesehatan Indonesia. 2015. (diakses 20 Januari 2017).

Sudarmanto. Perencanaan Tenaga kerja, Jakarta: Bina Diknakes; 2004. 
Dewi, Wiku. hubungan karakteristik perawat, isi pekerjaan dan lingkungan pekerjaan terhadap kepuasan kerja perawat di instalasi rawat inap RSUD Gunung Jati Cirebon. Makara Kesehatan VOL. 9, NO. 1, JUNI 2005: 1-8

https://staff.blog.ui.ac.id/wiku-a/files/2009/10/hubungan-karekteristik-perawat-isipekerjaan.pdf

Nursalam. Metodologi penelitian ilmu keperawatan, edisi 3. Jakarta: Salemba Medika. 2014

Aiken, L. H., Clarke, S. P., Sloane, D. M., Sochalski, J., dan Silber, J. H.. Hospital nurse staffing and patient mortality, nurse burnout, and job dissatisfaction. Journal of the American Medical Association.2001;288(16): 1987- 1993.

Khotimah, Kusnul. Hubungan antara Persepsi terhadap Lingkungan Kerja Psikologis dengan burn out pada Perawat RSU Budi Rahayu Pekalongan. Semarang: FPUNDIP ; 2010.

Ruth Vania C. Perawat Jatuhkan Bayi Baru Lahir dari Gendongannya, TribunNews 2 juli 2015., URL : http://www.tribunnews.com/internasional /2015/07/02/ngantuk-perawatjatuhkan-bayi-baru-lahir-dari-gendongannya

Luh, Ni P D Y. hubungan beban kerja, faktor demografi, locus of control dan harga diri terhadap burnout syndrome pada perawat pelaksana IRD RSUP Sanglah. COPING Ners Journal. Mei-Agustus 2015;3(2):51-60. ISSN: 2303-1298

Ayu P, Triyoga A. kejenuhan kerja (burnout) dengan kinerja perawat dalam pemberian asuhan keperawatan. Jurnal STIKES. Desember 2012:5(2);167-178. URL : puslit2.petra.ac.id/ejournal/index.php/stikes/article/download/18 613/18375.

Perawat stress patahkan tulang iga pasien, DetikNews 12 Maret 2010,. URL : http://news.detik.com/berita/1317292/perawat-stres-patahkan-tulang-iga-pasien

British nurses stressed out, underpaid, under-valued and their sex lives suffer, NewsMedical 29 mei 2007, URL : http://www.news-medical.net/news /2007 /05/29/25699.aspx

Rifiani, Nisya dan Sulihandari. Prinsip-Prinsip Dasar Keperawatan. Jakarta: Dunia Cerdas; 2013.

Undang-Undang Republik Indonesia Nomor 38 Tahun 2014 Tentang Keperawatan.

Potter, Patricia. Perry, Anne G. Buku Ajar Fundamental Keperawatan: Konsep, Proses, dan Praktik. Volume 1. Edisi 4. Jakarta: EGC; 2005

Sukma, Nolo, Widyawati. Konsep Dasar Keperawatan. Jakarta: Prestasi Pustaka; 2012

Depkes, RI. UU No. 44 Tahun 2009 Tentang Rumah Sakit. Jakarta : Depkes RI ; 2009

Drajad, Hentyn R. Hubungan antara kecerdasan emosi dan iklim organisasi dengan burnout pada pegawai KPP Pratama Sleman. Skripsi Psikologi Universitas Sebelas maret. 25 mei 2016 (diakses 23 januari 2017). Diunduh dari: URL: http://abstrak.ta.uns.ac.id/wisuda/upload/G0112049_bab2.pdf

Nurjayadi, Rostiana.Kejenuhan Kerja (Burnout) pada Karyawan. Jurnal Phronesis.2004;6(11)

Suryani. Dkk. Pengaruh kesejateraan spiritual (spiritual well being) dan letak kendali (locus of control) terhadap burnout kerja perawat di RS UNHAS Makasar. JST Kesehatan. April 2016;6(2):162-171.

Alimul A. Metode Penelitian Keperawatan dan Teknk Analisa Data. Edisi ke-1. Jakarta: Salemba Medika; 2013

Setiadi. Konsep dan Praktek Penulisan Riset Keperawatan, Edisi 2. Yogyakarta: Graha Ilmu; 2013 
Ambarwati, D. Pengaruh Beban Kerja Terhadap Stres Perawat IGD dengan Dukungan Sosial sebagai Variabel Moderating (Studi Pada RSUP Dr. Kariadi Semarang). Skripsi Pada Universitas Diponegoro. 24 juni 2014 (diakses 30 maret 2017). Diunduh dari: URL: http://eprints.undip.ac.id/43376/1/01__AMBARWATI.pdf

Kennedy, Lisa S., Komunikasi untuk keperawatan : berbicara dengan pasien, edisi 2, Jakarta : Erlangga ; 2009

Wayan, Sudarta.1., Managemen keperawatan: penerapan teori model dalam pelayanan keperawatan. Yogyakarta : Gosyen Publishing ; 2015

S. Pohan, Imbalo, Jaminan Mutu layanan kesehatan, Jakarta: EGC; 2004

Suharti, Nely., Helena, CD., Burnout kinerja perawat di rumah sakit metropolitan medical center Jakarta. Universitas Indonesia. Agustus 2015 (diakses 4 mei 2017). URL : http://lib.ui.ac.id/naskahringkas/2015-08/S46561 -neli\%20suharti

Ramdan, Iwan M., Nursan, Oktavian F., Analisis faktor yang berhubungan dengan burnout pada perawat kesehatan jiwa. Universitas Mulawarman. 2 Agustus 2016; 4; 170-178

Ayu, P A S S., Adiputra, Nyoman. Hubungan antara masa kerja dengan burnout pada perawat di ruang rawat inap anak RSUP Sanglah Denpasar:E-Jurnal Medika, April 2017; 6(4); $10-19$

Mariyanti, Sulis., Citrawati, Anisah., Burnout pada perawat yang bertugas di ruang rawat inap dan rawat jalan RSAB Harapan Kita; Jurnal Psikologi, Desember 2011; 9(2); 48-59

Sihotang, I, N. 2004. Burnout Pada Keryawan Ditijau Dari Persepsi Terhadap Lingkungan Kerja Psikologis Dan Jenis Kelamin. Jurnal Psyche. Fakultas Psikologi: Universitas Bina Darma Palembang, 2004 ; 10-17

Arturo, Juan Djara., Perbedaan kelelahan kerja (burnout) antara perawat lai-laki dan perawat perempuan di RSUD Kota Seo, Skripsi Universitas Kristen satya wacana ; 2013, URL :http://repository.uksw.edu/bitstream/123456789/6781/2/T1_802009139_Full\%20text. pdf

Hariyono, Widodo., Suryani, Diah., dan Wulandari, Yayuk. Hubungan Antara Beban Kerja, Stress Kerja Dan Tingkat Konflik Dengan Kelelahan Kerja Perawat Di Rumah Sakit Islam Yogyakarta PDHI Kota Yogyakarta. Kes Mas. Vol. 3, No. 3, September 2009 : 162-232.

Triwijayanti, R., Dwiantoro, L., Edi, B W. Analisis Karakteristik Individu Terhadap Kejenuhan. Jurnal of nursing and health (JNH). Akper Yakpermas-Banyumas; Agustus 2016; 2(1); 35-40.

Davydovich, D.K. The Medical-Social and the forensic-Psychiatric Aspects of Gerontology and Geriatric Psychiatry. 2017

Febriani, Limonu. Hubungan Motivasi Kerja Dengan Burnout Pada Perawat di IRD RSUD Dr. M. M Dunda Limboto Kabupaten Gorontalo. Skripsi Universitas Negeri Gorontalo ; 2014, URL : http://eprints.ung.ac.id /5265/5/2013-1-14201-841409084-bab226072013021053.pdf 